\title{
Making Waves in Ocean Policy
}

\section{OCEANOGRAPHY HAS A LONG TRADITION of}

publishing articles and full magazine issues that touch on the intersection of ocean science, management, and policy. We regularly publish the annual Revelle Lecture, which "highlights the important links between ocean science and public policy" (e.g., Brewer, 2000; Pomponi, 2001; McNutt, 2002; Orbach, 2003; Alley, 2004; Pielke, 2006; Caldeira, 2007). And occasionally we have published other articles related to some aspect of ocean policy, ocean science infrastructure, or broad ocean research and technical challenges (e.g., Watkins, 1995, 2002; Briscoe et al., 2004; Briscoe, 2005; Brandt, 2006; Baker et al., 2007; Abbott, this issue). Full magazine issues, such as the special issue on "The Oceans and Human Health" (19[2], June 2006), have provided more extensive coverage of particular themes that are of great interest to both scientists and policy-makers.

Public policy decision-making related to significant issues such as ocean acidification, ocean fertilization, fisheries management, marine protected areas, and ocean mining would benefit from broad public access to the best possible oceanographic information. The time is right for Oceanography to more regularly publish scientific articles that have direct relevance to these issues and more. We plan to solicit some articles on "hot" topics, but also hope to receive enough highquality unsolicited contributions to present at least one article related to ocean science policy and management in every issue. We particularly seek scientific articles that emphasize topics of direct social relevance and that demonstrate how the authors' research has the potential to inform policy decisions. We also seek provocative articles that will start a community discussion on the future direction of ocean science. The format for these peer-reviewed articles is flexible.

In an ideal world, staff and assistants to policy- and decision-makers whose work requires an understanding of the most up-to-date and relevant science would peruse Oceanography every quarter, or have the magazine's Web page bookmarked. In reality, it takes people to physically hand them the articles and point out particularly relevant information-or at least email relevant portions to a Blackberry or Treo. We hope that many articles printed in this new section will be distributed in this manner.

On this twentieth anniversary of The Oceanography Society, what can be a better tribute to the Society than to make it even more relevant?

\section{REFERENCES}

Alley, R.B. 2004. Abrupt climate changes: Oceans, ice, and us. Oceanography 17(4):194-206.

Baker, D.J., R.W. Schmitt, and C. Wunsch. 2007. Endowments and new institutions for long-term observations. Oceanography 20(4):10-14.

Brandt, A. 2006. Grand challenges for ocean science research. Oceanography 19(2):14-17.

Brewer, P.G. 2000. Contemplating action: Storing carbon dioxide in the ocean. Oceanography 13(2):84-92.

Briscoe, M. 2005. The US Commission on Ocean Policy and the White House Ocean Action Plan. Oceanography 18(3):9-13.

Briscoe, M., A. Clark, P. Jumars, M. McNutt, and J. Yoder. 2004. The US Commission on Ocean Policy: Why you should care and what you can do. Oceanography 17(3):6-11.

Caldeira, K. 2007. What corals are dying to tell us about $\mathrm{CO}_{2}$ and ocean acidification. Oceanography 20(2):188-195.

McNutt, M. 2002. Ocean exploration. Oceanography 15(1):112-121.

Orbach, M. 2003. Beyond the freedom of the seas: Ocean policy for the third millennium. Oceanography 16(1):20-29.

Pielke, R.A. Jr. 2006. Disasters, death, and destruction: Making sense of recent calamities. Oceanography 19(2):138-147.

Pomponi, S.A. 2001. The oceans and human health: The discovery and development of marine-derived drugs. Oceanography 14(1):78-87.

Watkins, J.D. 1995. Linking public policy support for ocean science to pre-college education. Oceanography 8(3):103-105.

Watkins, J.D. 2002. US Commission on Ocean Policy. Oceanography 15(4):4-6.

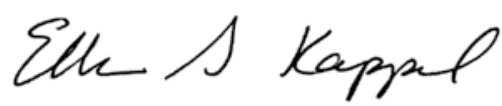

ELLEN S. KAPPEL, EDITOR 